ŁUKASZ DOMINIAK

Instytut Politologii UMK

\title{
Wolnomyśliciel Russell
}

B

ertrand Russell to prawdopodobnie ostatni człowiek renesansu. Spod jego pióra wyszły woluminy traktujące o logice, matematyce, filozofii, teorii poznania, historii, pedagogice oraz socjologii, zwłaszcza zaś eseistyka społeczno-polityczna. Literacki noblista roku 50. osiągnął poziom intelektualnej syntezy dalece przewyższający ówczesną epokę. Od ścisłości Principia Mathematica, gdzie podjął próbę rozsupłania antynomii teoriomnogościowych i redukcji matematyki do logiki (logicyzm), poprzez pisarską swadę Dziejów filozofii Zachodu („Kant powszechnie uchodzi za największego z filozofów nowożytnych. Nie mogę zgodzić się z tą opinią...”), do talentu popularyzatorskiego (niematematyczny wstęp do teorii względności), Russell jawi się jako jeden z największych (a na pewno najbardziej wszechstronnych) myślicieli współczesnych.

Powyższy pamflet, będący pismem akroamatycznym (co widać choćby w jego niezbyt wyszukanej stylistyce), nieznany polskiemu czytelnikowi, jest tekstem, można rzec, peryferyjnym w dorobku autora Matżeństwa i moralności. Niemniej, porusza co najmniej dwa wątki, które przedstawione w innych miejscach, są dla Russella charakterystyczne i ważne. Pierwszym z nich jest zawarty implicite w szkicu tzw. problem Hume'a. Drugim, wynikający z problemu Hume'a, wątek racjonalności.

Problem Hume'a jest (jak to jako pierwszy zauważył Karl R. Popper w Ein Kryterium des empirischen Charakters theoretischer Systeme, „Erkenntnis”, 
nr 3, 1933, s. 426) problemem indukcji. Sprowadza się on do pytania: Czy wnioskowanie ze znanych z doświadczenia przypadków o innych przypadkach, nieznanych z doświadczenia jest prawomocne? Odpowiedź Hume’a była oczywiście negatywna.

Sądzę, że Russell mówiąc powyżej o doktrynie stopni prawdopodobieństwa próbuje formułować swoją odpowiedź na problem Hume’a. Nie możemy być pewni zajścia w przyszłości przypadków, które znamy z doświadczenia, nawet jeśli są przedmiotem opisu nauki, ale powinniśmy sądzić, iż prawdopodobieństwo ich zajścia jest bliskie pewności. W Problemach filozofii Russell wyraził tę myśl tak oto: „Im częściej znajduje się te rzeczy razem, tym bardziej prawdopodobne się staje, że znajdzie się je razem kiedy indziej, i że jeśli znajdowano je razem dostatecznie często, to prawdopodobieństwo to staje się niemal równe pewności. Nigdy nie osiągnie pewności zupełnej, wiemy bowiem, iż pomimo częstych powtórzeń czasem w końcu zdarzają się niepowodzenia." Propozycja ta jest nieudana i parafrazując słowa Jestem ateista czy agnostykiem? można rzec, że doktryna stopni prawdopodobieństwa jest rodzajem doktryny, której świat nie potrzebuje.

Russell sam, jak mniemam, zdawał sobie sprawę, iż jego odpowiedź na problem indukcji jest niewystarczająca. W Dziejach filozofii Zachodu trochę kpiarsko zauważył: „Należy zbadać, czy można dać jakąkolwiek odpowiedź Hume'owi w ramach filozofii opartej całkowicie lub w głównej mierze na doświadczeniu. Jeśli nie, to nie ma żadnej intelektualnej różnicy między rozsądkiem i szaleństwem. Wariata, który jest przekonany, że jest gotowanym jajem, można krytykować tylko na tej podstawie, że jest w mniejszości." Russell dostrzegał, że jeśli przyjmie się wszelkie konsekwencje Hume’a, czyli odrzuci zasadę indukcji jako nieprawdziwą logicznie i nieprawdziwą empirycznie, to nauka stanie się niemożliwa. Zaproponował więc, aby traktować zasadę indukcji jako niezależną zasadę logiczną, której przyjęcie pozwoli uważać całość wiedzy (z wyjątkiem tej zasady) jako opartą na doświadczeniu. Była to propozycja niesatysfakcjonująca. Problem indukcji rozwiązał nie Russell, lecz Popper przedstawiając teorię dedukcyjnej metody sprawdzania.

Problem racjonalności jest właściwie pytaniem o kryterium delimitacji myślenia racjonalnego i nieracjonalnego. To kryterium widzi Russell w oparciu naszych twierdzeń i działań na doświadczeniu. Postuluje on, aby „opierać swe argumenty na podstawie, która jest akceptowana przez naukę", czyli właśnie na doświadczeniu. Dodaje do tego szczyptę sceptycyzmu, czyli zamienia pewność na prawdopodobieństwo. Jako ciekawostkę można wskazać fakt, iż taka definicja racjonalności jest tożsama z definicją istoty liberalizmu. W eseju Filozofia i polityka Russell pisze, iż: „W światopoglądzie liberalnym nie chodzi o to, jakie opinie się wyznaje, ale jak się je wyznaje - nie 
w sposób dogmatyczny, lecz niejako na próbę, ze świadomością, że nowe fakty mogą w każdej chwili doprowadzić do ich obalenia." Jest to oczywiście ta sama definicja, którą spotykamy w Jestem ateista czy agnostykiem?, gdzie Russell określa racjonalizm: „Istotny jest bowiem sposób, w jaki dochodzisz do swych opinii a nie jaka jest tych opinii treść."

Atoli definicja ta również nie jest dobra. Wracamy do problemu Hume'a. Skoro zasada indukcji jest błędna, to oczekiwanie i wiara „rozumnych" ludzi, iż przewidywania bazujące na doświadczeniu okażą się z wielkim prawdopodobieństwem prawdziwe, są oparte nie na racji, lecz na „przyzwyczajeniu lub nawyku", czyli są wiarą irracjonalną. Nie ma więc różnicy między człowiekiem racjonalnym a abderytą. Paradoks ten również został rozwiązany przez Poppera. Kryterium demarkacji myślenia racjonalnego i nieracjonalnego to wg Poppera krytyczny stosunek do naszych teorii, hipotez, domysłów. Jak zauważył w Wiedzy obiektywnej: „nie znajduję lepszego synonimu dla pojęcia racjonalny niż pojęcie krytyczny". Jest to oczywiście kryterium wynikające z i zrozumiałe dopiero w popperowskim rozwiązaniu problemu Hume'a i Kanta (czyli problemu demarkacji wiedzy).

Ogólnie rzecz biorąc, Czy jestem ateista, czy agnostykiem? jest esejem o charakterze popularyzatorskim. Czytelnik nie znajdzie w nim systematycznego wywodu, ścisłości dowodzenia, wyrafinowanej i pełnej argumentacji. Jest to bowiem zapis myśli żywej, błyskotliwych posunięć retorycznych przypominających raczej ruchy skoczka szachowego, zmieniającego wątki z pominięciem szeregu przesłanek i wniosków, niż konsekwentny gambit pionami, pociągający logicznie kolejne posunięcia. Motywy antychrześcijańskie nie są niczym nadzwyczajnym w twórczości autora Dlaczego nie jestem chrześcijaninem?, mają za zadanie rzucenie czarów autorytetu, riposty, kpiny, zręcznej sofistyki na czytelnika albo młodego, albo letniego, albo już apostatę. Czystą retoryką jest oczywiście zrównanie chrześcijaństwa z grecką mitologią, o różnicach między nimi człowieka wykształconego, nawet areligijnego, przekonywać bowiem nie trzeba. Russell też o tym wie i dlatego m.in. zajmuje się zwalczaniem właśnie chrześcijaństwa a nie mitologii, tę odrzucono na długo przed Russellem i za pomocą innego rodzaju argumentów. Główną ideą tekstu nie jest przecież nawet sugerowana przez tytuł problematyka wiary, lecz afirmacja ludzkiego rozumu jako najwyższego osiągnięcia człowieka. Ten cel udaje się Russellowi bez wątpienia realizować, realizować całością tego, co Grecy określali jako bios theoretikos. 